\title{
Kepemimpinan, Kedisiplinan, dan Kepuasan Kinerja Guru PNS Sekolah Dasar
}

\author{
Susilowati \\ STIE Cendekia Karya Utama \\ susicherizz@gmail.com
}

\begin{abstract}
The focus of this research is the influence of leadership, discipline and teacher satisfaction with the performance of civil servants in the district Jekulo rate in elementary. The purpose of this study was to determine and analyze the impact of school leadership, discipline and satisfaction with the performance of primary school teachers in the district PNS Jekulo. The method in this research is quantitative. Data collection techniques are interviews and observation. The results of the analysis leads to the conclusion of school leadership directly affects the performance of teachers, discipline has no direct influence on the performance of teachers because kedisilpinan has become the custom of a rule that must be followed by teachers, job satisfaction has no direct influence on the performance of teachers, leadership directly influence job satisfaction, kedisilpinanberengaruh directly against complacency, no school leadership indirect effect on teacher performance through customer satisfaction and discipline indirect effect on the performance of teachers through job satisfaction.
\end{abstract}

Keywords:Leadership, Dicipline, Satisfaction performance.

\begin{abstract}
Abstrak. Fokus penelitian ini adalah pengaruh kepemimpinan, kedisiplinan dan kepuasan terhadap kinerja guru PNS sekolah dasar di kecamatan Jekulo. Tujuan penelitian ini adalah mengetahui dan menganalisis pengaruh kepemimpinan kepala sekolah, kedisiplinan dan kepuasan terhadap kinerja guru PNS sekolah dasar di kecamatan Jekulo. Metode dalam penelitian ini adalah kuantitatif. Teknik pengumpulan data yaitu wawancara dan observasi. Hasil analisis mengarah pada kesimpulan kepemimpinan kepala sekolah berpengaruh langsung terhadap kinerja guru, kedisiplinan tidak berpengaruh secara langsung terhadap kinerja guru karena kedisilpinan sudah menjadi hal kebiasan suatu peraturan yang harus dipatuhi oleh guru, kepuasan kerja tidak berpengaruh secara langsung terhadap kinerja guru, kepemimpinan berpengaruh langsung terhadap kepuasan kerja, kedisilpinan berpengaruh langsung terhadap kepuasan, kepemimpinan kepala sekolah tidak berpengaruh secara tidak langsung terhadap kinerja guru melalui kepuasan dan kedisiplinan berpengaruh secara tidak langsung terhadap kinerja guru melalui kepuasan kerja.
\end{abstract}

Kata Kunci: Kepemimpinan, Kedisiplinan, Kepuasan, Kinerja 


\section{Pendahuluan}

Pendidikan Nasional bertugas dan bertanggung jawab untuk menghantar bangsa ini agar siap menyongsong dan mampu bersaing dengan adanya era globalisasi dan perubahan menjadi peluang dan kemudian mengelolanya menjadi kekuatan yang mampu meningkatkan kualitas hidup kehidupan bangsa dan Negara di masa depan. Pendidikan perlu mengambil posisi dan peran nyata yang dinamis, proaktif, interaktif, serta berorientasi ke masa depan. Artinya pendidikan harus mampu bergerak lugas dalam menghadapi rintangan-rintangan dan memanfaatkan peluang yang ada. Pemerintah saat ini sedang berusaha meningkatkan kesejahteraan masyarakat di segala bidang.

Peningkatan mutu pendidikan ditentukan oleh kesiapan sumber daya manusia yang terlibat dalam proses pendidikan. Guru merupakan salah satu faktor penentu tinggi rendahnya mutu hasil pendidikan mempunyai posisi strategis maka setiap usaha peningkatan mutu pendidikan perlu memberikan perhatian besar kepada peningkatan guru baik dalam segi jumlah maupun mutunya.

Aspek kinerja guru merupakan aspek penting yang perlu diperhatikan. Menjaga dan mengupayakan guru supaya memiliki kinerja yang tinggi mutlak diperlukan untuk menciptakan sumber daya manusia yang berkualitas. Faktor-faktor yang mempengaruhi terhadap pembentukan kinerja guru perlu segera dicari jawabannya agar rendahnya kualitas pendidikan di kecamatan Jekulo yang antara lain diduga karena adanya faktor kepemimpinan kepala sekolah, kedisiplinan dan kepuasan menurut persepsi guru. Atas dasar pemikiran dan dugaan tersebut peneliti tertarik untuk melakukan penelitian mengenai kinerja guru PNS sekolah dasar di kecamatan Jekulo dalam hubungannya dengan kepemimpinan kepala sekolah, kedisiplinan dan kepuasan.

Kinerja adalah hasil kerja secara kualitas dan kuantitas yang dicapai oleh seorang pegawai dalam melaksanakan tugasnya sesuai dengan tanggung jawab yang diberikan kepadanya. Tinggi rendahnya kinerja pekerja berkaitan erat dengan sistem pemberian penghargaan yang diterapkan oleh lembaga atau organisasi tempat mereka bekerja. Pemberian penghargaan yang tidak tepat dapat berpengaruh terhadap peningkatan kinerja seseorang Mangkunegara (2001). Kinerja adalah sesuatu yang dicapai, prestasi yang diperlihatkan atau kemampuan kerja yang dimiliki seorang tenaga kerja (Siregar, 2011).

Berkenaan dengan standar kinerja guru, Piet A Sahertian (dalam Rusman, 2010) menjelaskan bahwa 'standar kinerja guru itu berhubungan dengan kualitas guru dalam 
Philanthrophy Journal of Psychology

Vol 2 Nomor 2 (2018), 88-96

ISSN 2580-6076 (Print), ISSN 2580-8532 (Online)

menjalankan tugasnya seperti bekerja dengan siswa secara individual, persiapan dan perencanaan pembelajaran, melibatkan siswa dalam berbagai pengalaman belajar dan kepemimpinan yang aktif dari guru'. Untuk mencapai tujuan pembelajaran, tentunya guru harus mempersiapkan perangkat yang harus dilaksanakan dalam merencanakan program pembelajaran. Berikut ini beberapa perangkat yang harus dipersiapkan dalam kegiatan pembelajaran, antara lain : (a) Membuat silabus pembelajaran; (b) Membuat rencana pelaksanaan pembelajaran; (c) Membuat dan mempersiapkan media atau alat peraga pembelajaran; (d) Membuat instrumen tes; (e) Menguasai bahan pengajaran; (f) Membuat format penilaian.

Kepemimpinan menurut Andang (2014) adalah suatu proses yang dilakukan untuk mempengaruhi seseorang atau sekelompok orang untuk bekerja secara bersama tanpa paksaan dalam mencapai tujuan dari suatu organisasi. Robbins (2006) mengatakan kepemimpinan adalah kemampuan untuk mempengaruhi sekelompok anggota agar bekerja mencapai tujuan dan sasaran. Kepemimpinan dapat menentukan apakah suatu organisasi mampu mencapai tujuan-tujuan yang ditetapkan. Danim (2009), memberikan definisi kepemimpinan sebagai kemampuan memengaruhi dan memberi arah yang terkandung didalam diri pribadi pemimpin. Gibson sebagaimana dikutip Nawawi (2003) mengatakan kepemimpinan adalah seni menggunakan berbagai jenis pengaruh yang bukan paksaan untuk memotivasi anggota organisasi untuk mencapai tujuan.

Pengertian disiplin dapat dikonotasikan sebagai suatu hukuman, meskipun arti yang sesungguhnya tidaklah demikian. Disiplin berasal dari bahasa latin"Disciplina" yang berarti latihan atau pendidikan kesopanan dan kerohanian serta pengembangan tabiat. Jadi sifat disiplin berkaitan dengan pengembangan sikap yang layak terhadap pekerjaan. Pengertiaan kedisiplinan menurut Hasibuan (2012) adalah sebagai berikut: "Kedisiplinan adalah kesadaran dan kesediaan seseorang mentaati semua peraturan organisasi dan norma-norma sosialyang berlaku. Kesadaran adalah sikap seseorang yang secara sukarela mentaati semua peraturan dan sabar akan tugas dan tanggungjawabnya, jadi dia akan mematuhi/mengerjakan semua tugasnya dengan baik, bukan atas paksaan. Kesediaan adalah suatu sikap, tingkah laku dan perbuatan seseorang yang sesuai dengan peraturan organisasi baik yang tertulis maupun tidak."

Setiap orang yang bekerja mengharapkan memperoleh kepuasan dari tempatnya bekerja. Pada dasarnya kepuasan kerja merupakan hal yang bersifat individual karena setiap individu akan memiliki tingkat kepuasan yang berbeda-beda sesuai dengan nilainilai yang berlaku dalam diri setiap individu. Semakin banyak aspek dalam pekerjaan yang sesuai dengan keinginan individu, maka semakin tinggi tingkat kepuasan yang dirasakan. 
Philanthrophy Journal of Psychology

Vol 2 Nomor 2 (2018), 88-96

ISSN 2580-6076 (Print), ISSN 2580-8532 (Online)

Menurut Kreitner dan Kinicki (2001) kepuasan kerja adalah "suatu efektifitas atau respon emosional terhadap berbagai aspek pekerjaan". Davis dan Newstrom (1985) mendeskripsikan "kepuasan kerja adalah seperangkat perasaan pegawai tentang menyenangkan atau tidaknya pekerjaan mereka".

Keberhasilan pendidikan di sekolah sangat ditentukan oleh kinerja gurunya. Seorang guru yang mempunyai kinerja tinggi seharusnya mempunyai sikap positif terhadap pekerjaan yang menjadi tanggung jawabnya, sikap tersebut misalnya disiplin, menjaga kualitas kerjanya, bertanggung jawab, dan sebagainya. Kenyatan menunjukkan masih terdapat guru yang sering terlambat datang, guru kurang persiapan dalam mengajar dan jarang membuat RPP hasil sendiri. Banyak guru yang disiplin, tetapi hanya saja masih ada guru yang tidak disiplin dalam mengajar, seperti terlambat masuk kelas setelah selesai istirahat. Selain itu juga masih ada guru yang mengajar menggunakan metode monoton yang berpacu pada buku panduan saja, masih ada juga kepala sekolah yang belum memberikan penghargaan seperti memberikn pujian pada hasil kinerja guru sehingga dapat meningkatkan kinerja guru yang seutuhnya.

Segala permasalahan diatas didukung pula dengan hasil UKG menyatakan masih dibawah rata-rata. Kasi Pendidikan dan Ketenaga Kependidikan pada Dinas Pendidikan Pemuda dan Olahraga (Disdikpora) Kudus Witono mengatakan dari beberapa hasil UKG yang ada nilai guru masih dibawah rata-rata. Nilai lolos UKG sendiri menurut Witono, adalah 80. Namun yang terjadi, nilai masih antara 60-70. Banyak kendala yang mempengaruhi kinerja guru-guru tersebut, seperti sikap kepemimpinan kepala sekolahnya, ketaatan guru terhadap peraturan dan dari ketidaksiapan guru saat mengajar. Hasil UKG dan dari kegiatan prasurvey masih ada guru yang belum optimal kinerjanya jika dibandingkan teori dari empat kompetensi di atas terjadi kesenjangan, yaitu antara teori dan kenyataan terjadi perbedaan, maka dari itu kinerja guru yang sebenarnya layak dikaji melalui penelitian yang akan peneliti lakukan.

Masalah yang dipilih dipandang layak untuk diteliti karena beberapa alasan antara lain (1) semakin rendahnya kinerja guru sekolah dasar di kecamatan Jekulo (2) Peranan kepala sekolah, kedisiplinan serta kepuasan adalah merupakan faktor yang membuat kinerja guru menjadi rendah.

Berdasar latarbelakang permasalahan sebagaimana diuraikan di atas, dapat diambil pokok permasalahan sebagai berikut: (1) Apakah kepemimpinan kepala sekolah berpengaruh terhadap kinerja guru PNSsekolah dasar di kecamatan Jekulo? (2) Apakah kedisiplinan berpengaruh terhadap kinerja guru PNS sekolahdasar di kecamatanJekulo? (3) Apakah kepuasan kerja berpengaruh terhadap kinerja guru PNS sekolah dasar di 
Philanthrophy Journal of Psychology

Vol 2 Nomor 2 (2018), 88-96

ISSN 2580-6076 (Print), ISSN 2580-8532 (Online)

kecamatan Jekulo? (4) Apakah kepemimpinan kepala sekolah berpengaruh terhadap kepuasan kerja guru PNS sekolah dasar di kecamatan Jekulo? (5) Apakah kedisiplinan berpengaruh terhadap kepuasan kerja guru PNS sekolah dasar di kecamatan Jekulo? (6) Apakah kepemimpinan kepala sekolah berpengaruh tidak langsung terhadap kinerja melalui kepuasan kerja guru PNS sekolah dasar di kecamatan Jekulo? (7) Apakah kedisiplinan berpengaruh tidak langsung terhadap kinerja melalui kepuasan guru PNS sekolah dasar dikecamatan Jekulo?

Tujuan penulisan artikel ini adalah (1) Mengetahui dan menganalisis pengaruh kepemimpinan kepala sekolah terhadap kinerja guru PNS sekolah dasar di kecamatan Jekulo? (2) Mengetahui dan menganalisis pengaruh kedisiplinan terhadap kinerja guru PNS sekolahdasar di kecamatanJekulo? (3) Mengetahui dan menganalisis pengaruh kepuasan kerja terhadap kinerja guru PNS sekolah dasar di kecamatan Jekulo? (4) Mengetahui dan menganalisis pengaruh kepemimpinan kepala sekolah terhadap kepuasan kerja guru PNS sekolah dasar di kecamatan Jekulo? (5) Mengetahui dan menganalisis pengaruh kedisiplinan terhadap kepuasan kerja guru PNS sekolah dasar di kecamatan Jekulo? (6) Mengetahui dan menganalisis pengaruh kepemimpinan kepala sekolah berpengaruh tidak langsung terhadap kinerja melalui kepuasan kerja guru PNS sekolah dasar di kecamatan Jekulo? (7) Mengetahui dan menganalisis kedisiplinan berpengaruh tidak langsung terhadap kinerja melalui kepuasan guru PNS sekolah dasar dikecamatan Jekulo?

\section{Metode}

Penelitian ini mengguakan metode deskriptif kuantitatif. Teknik pengumpulan data dengan wawancara, observasi dan dokumentasi dan penyebaran angket. Teknik analisis data yang digunakan path analisis.

\section{Hasil dan Diskusi}

\section{Pengaruh kepemimpinan terhadap kinerja guru}

Berdasarkan deskripsi data dapat dijelaskan bahwa sebagian besar guru menyatakan kepemimpinan kepala sekolah SD di kecamatan Jekulo Kabupaten Kudus termasuk dalam kategori baik dan rata-rata menyatakan bahwa kepala sekolah dalam mempimpin dapat diterima oleh guru. Hasil yang didapat dari jawaban angket guru sekolah dasar di kecamatan Jekulo menunjukkan bahwa kinerja guru didukung kepemimpinan kepala sekolah dan setiap perubahan/peningkatan variabel kepemimpinan kepala sekolah akan menentukan hasil kinerja guru. Hasil analisis data diperoleh dari 
Philanthrophy Journal of Psychology

Vol 2 Nomor 2 (2018), 88-96

ISSN 2580-6076 (Print), ISSN 2580-8532 (Online)

persamaan garis regresi linier yaitu $38.874+0.564 \mathrm{X}_{1}$ yang dapat diinterprestasikan, jika tidak ada kepemimpinan kepala sekolah maka kinerja guru hanya sebesar 38.874 . Koefisien regresi mempunyai arti bahwa setiap penambahan kepemimpinan kepala sekolah sebesar 1\% maka akan mempengaruhi kinerja guru sebesar $0.564 \%$. hal ini berarti menunjukkan kepemimpinan berpengaruh terhadap kinerja guru.

\section{Pengaruh kedisiplinan terhadap kinerja guru}

Berdasarkan hasil deskripsi dapat dijelaskan bahwa menurut sebagian besar dan rata-rata tanggapan responden terhadap kedisiplinan guru sekolah dasar di kecamatan Jekulo sudah kondusif atau baik. Namun demikian masih ada guru kurang disiplin, tetapi kebanyakan dari resonden atau guru sekolah dasar di kecamatan Jekulo sudah sangat baik sehingga tidak berpengaruh terhadap kinerja yang mereka lakukan. Hal ini berarti disipin bukan hal utama yang mempengaruhi kinerja guru secara langsung karena dari peraturan yang sudah dibuat oleh dinas daerah maupun provinsi guru wajib mentaatinya sehingga sudah menjadi kebiasaan bagi guru sekolah dasar di kecamatan Jekulo. Hasil penelitian menunjukkan bahwa kedisiplinan tidak berpengaruh secara langsung terhadap kinerja guru yaitu ditunjukkan dengan nilai yang hasilnya negatif sebesar $-1.9 \%$. Hasil pengujian individual kedisiplinan menunjukkan nilai unstandarlized coeffisients beta sebesar -0.019 dan $(\mathrm{p}=0.865)$ menunjukkan tidak signifikan pada $<0.1$.

\section{Pengaruh kepuasan terhadap kinerja guru}

Berdasarkan hasil diskripsi dapat dijelaskan bahwa menurut sebagian besar dan rata-rata tanggapan responden terhadap kepuasan guru sekolah dasar di kecamatan jekulo sudah baik. Namun demikian masih ada guru yang belum puas terhadap kinerjanya, tetapi kebanyakan dari responden atau guru sekolah dasar kepuasan kerja mereka sudah sangat baik sehingga tidak berpengaruh terhadap kinerja yang mereka lakukan. Hal ini ditunjukkan dengan hasil penelitian bahwa kepuasan tidak berpengaruh terhadap kinerja guru yaitu dengan nilai hasil statistik sebesar 0.015 dan $(\mathrm{p}=0.853)$ yang berarti tidak signifikan pada $<0.1$.

\section{Pengaruh kepemimpinan terhadap kepuasan}

Berdasarkan diskripsi data dijelaskan bahwa sebagian besar guru menyatakan kepemimpinan kepala sekolah di SD kecamatan Jekulo termasuk dalam kategori baik walaupun masih ada guru yang belum bisa menerima cara kepemimpinan kepala sekolah di SD kecamatan Jekulo. Hasil data jawaban angket yang sudah dihitung menunjukkan 
Philanthrophy Journal of Psychology

Vol 2 Nomor 2 (2018), 88-96

ISSN 2580-6076 (Print), ISSN 2580-8532 (Online)

bahwa kepemimpinan kepala sekolah berpengaruh terhadap kepuasan kinerja guru yaitu dengan hasil statistik sebesar 0.621 dan $(\mathrm{p}=000)$. Hal ini berarti kepuasan kerja guru akan meningkat jika hasil kinerjanya dihargai oleh pimpinan yaitu kepala sekolah.

\section{Pengaruh kedisilpinan terhadap kinerja}

Berdasarkan diskripsi data dapat dijelaskan bahwa sebagian guru menyatakan kedisiplinan mereka sudah sangat bagus sehingga membuat kepuasan tersendiri bagi guru sekolah dasar di kecamatan Jekulo. Guru yang kerjanya disiplin tinggi maka dapat menyelesaikan semua tugas dengan tepat waktu dan tidak merasa beban dengan tugas yang diberikan sehingga guru akan merasa senang dalam menjalankan tugasnya baik di dalam sekolah maupun di luar sekolah. dengan demikian kepuasan guru ditentukan oleh kedisilpinan yang mereka lakukan. Hasil dari jawaban angket menunjukkan bahwa kedisplinan berpengaruh terhadap kepuasan guru yaitu dengan hasil statistik sebesar 0.299 dan $(\mathrm{p}=0.051)$.

\section{Pengaruh kepemimpinan terhadap kinerja guru melalui kepuasan}

Berdasarkan diskripsi data dapat dijelaskan bahwa sebagian besar guru sekolah dasar di kecamatan Jekulo menyatakan bahwa kepala sekolah termasuk dalam kategori baik, namun ada beberapa guru yang merasakan kinerjanya belum dihargai sehingga membuat kepuasan kerja guru berkurang dan membawa dampak negatif pada kinerja. Hasil dari jawaban angket guru menunjukkan kepemimpinan tidak berpengaruh secara tidak langsung terhadap kinerja guru melalui kepuasan kerja. Hal ini ditunjukkan dengan hasil statistik data sebesar 0.0093, sedangkan hasil pengaruh langsung dari kepemimpinan terhadap kinerja guru sebesar 0.564 sehingga menunjukkan kesimpulan hasil langsung lebih besar dari pada hasil tidak langsung melalui kepuasan.

\section{Pengaruh kedisiplinan terhadap kinerja guru melalui kepuasan}

Berdasarkan diskriptif data dapat dijelaskan bahwa menurut sebagian besar dan rata-rata tanggapan responden terhadap kedisiplinan guru sekolah dasar di kecamatan Jekulo sudah kondusif walaupun masih ada guru yang belum disiplin dalam bekerja. Guru yang disiplin akan membuat kinerja mereka dapat selesai tepat waktu sehingga menumbuhkan kepuasan tersendiri pada guru. Hal ini ditunjukkan dengan hasil penelitian bahwa kedisiplinan berpengaruh secara tidak langsung terhadap kinerja guru melalui kepuasan yaitu denga hasil statistik sebesar 0.0044 lebih besar dibanding hasil pengaruh kedisiplinan terhadap kinerja yaitu -0.019 . 


\section{Simpulan}

Kepemimpinan kepala sekolah berperan terhadap kinerja guru, sehingga kepemimpinan yang bijak dan tegas membuat guru lebih patuh pada peraturan yang telah menjadi tanggung jawab guru. Hal ini ditunjukkan dengan hasil penelitian bahwa kepemimpinan berpengaruh secara langsung terhadap kinerja guru sekolah dasar di kecamatan jekulo. Kedisiplinan yang sudah menjadi peraturan mutlak telah menjadi kebiasan yang harus dipatuhi oleh guru sehingga kedisiplinan tidak berpengaruh terhadap kinerja guru karena kedisiplinan adalah suatu hal yang sudah seharusnya dipatuhi seorang guru. Kepuasan tidak mempengaruhi kinerja guru karena guru yang sudah terbiasa bekerja dengan baik maka dan mematuhi peraturan itu tidak mempengaruhi kepuasan, kepemimpinan berpengaruh terhadap kepuasan guru karena kinerja guru merasa dihargai oleh kepala sekolah sehingga menimbulkan kepuasan tersendiri. Kedisiplinan yang tinggi akan membuat kinerja guru menjadi baik sehingga menimbulkan kepuasan kerja, hal ini ditunjukkan dengan hasil penelitian kedisiplinan berpengaruh terhadap kepuasan. Kepemimpinan tidak berpengaruh secara tidak langsung terhadap kinerja guru melalui kepuasan dan kedisilpinan berpengaruh tidak langsung terhadap kinerja guru melalui kepuasan karena kinerja yang baik dan dihargai kepala sekolah maka akan meningkatkan kepuasan kerja guru.

\section{Daftar Pustaka}

Andang. (2014). Manajemen dan Kepemimpinan Kepala Sekolah. Yogyakarta: Arr-Ruzz Media.

Danim, Sudarwan dan Suparno. (200). Manajemen dan Kepemimpinan Transformasional Kepala Sekolah. Jakarta: PT. Rineka Cipta.

Davis,K \& Newstrom, J.W. (1985). Perilaku Dalam Organisasi, edisi ketujuh. Jakarta: Penerbit Erlangga.

Hasibuan, M. (2012). Manajemen Daya Manusia, edisi revisi. Jakarta: Bumi Aksara.

Mangkunegara, AA \& Prabu, A. (2007). Manajemen Sumber Daya Manusia. Cetakan Ketujuh, Bandung : PT. Remaja Rosdakarya.

Nawawi, H. (2003). PerencanaanSDM Untuk Organisasi Profit YangKompetitif. Edisi Pertama, Cetakan Pertama, Gadjah Mada University Press, Yogyakarta.

Rusman. (2010). Model-Model Pembelajaran. Bandung: Alfabeta.

Robbins, PS. 2006. Perilaku Organisasi. Edisi kesepuluh. Jakarta: PT Indeks Kelompok Gramedia.

Robert, K dan Kinicki, A, (2001) . Organizational Behavior. http edition. Irwin McGrawHill. 
Philanthrophy Journal of Psychology

Vol 2 Nomor 2 (2018), 88-96

ISSN 2580-6076 (Print), ISSN 2580-8532 (Online)

Siregar, E. 2011. Pengaruh Motivasi Kerja, Kerja Individual dan Sistem Kompensasi Finansial terhadap Kepuasan kerja. Jurnal Pendidikan.

http://dapodik.pdkjateng.go.id/npsn pddk dasar/kecamatan/031900/sekolah/031905(d iunduh tanggal 26 Septemeber 2015). 